Al-Tanzim : Jurnal Manajemen Pendidikan Islam

E-ISSN: 2549-5720 P-ISSN: 2549-3663

March 2019, Vol. 03 No. 01, p. 82-101

https: / / journal.unuja.ac.id/ index.php/ al-tanzim

\title{
MANAJEMEN PENGEMBANGAN PONDOK PESANTREN (Studi Kasus di Pondok Pesantren As'adiyah Belawa Baru, Masamba, Sulawesi Selatan)
}

\author{
Yunus', Jazuli Mukhtar1, Ichwan Nugroho' \\ 1STMIK Eresha Pamulang, Banten \\ nurhang542@gmail.com
}

\section{Abstract :}

This study aims to determine the pattern of development strategy Boarding School in Malangke. Pattern or strategic used by the container or place in order to process a change of plans that require the support of all parties to develop and improve educational quality. In this study, researchers used a qualitative research and data sources through interviews with the leadership of the cottage. Boarding school development opportunities in the North Luwu, belonging to the sub-national education system in Indonesia that aims to educate the nation, making the man who is faithful and devoted to God Almighty, noble, healthy, knowledgeable, skilled, creative. In addition, the boarding school New Belawa As'adiyah, considered successful because studentsstudents directly involved in the community, for example in the Holy month of Ramadhan, these students were sent to be Imam in every mosque in Malangke. But beyond the success, there are some some of the barriers faced by Islamic Schools As'adiyah New Belawa (Malangke) include: 1) a more modern curriculum system, so that schools lag far from public schools, 2) Lack of funds and sources of funding due to lack of students. 3) the majority of parents are not keen to send children in school boarding school.

Key Words: Leadership Models; Transformational; Islamic Education 


\section{Al-Tanzim : Jurnal Manajemen Pendidikan Islam \\ E-ISSN: 2549-5720 P-ISSN: 2549-3663 \\ March 2019, Vol. 03 No. 01, p. 82-101 \\ bttps:// ejournal.unuja.ac.id/index.php/al-tanzim}

\section{Abstrak :}

Penelitian ini bertujuan untuk mengetahui pola strategi pengembangan Pondok Pesantren di Malangke. Pola atau strategi yang digunakan oleh wadah atau tempat guna proses suatu perubahan berencana yang memerlukan dukungan semua pihak dalam mengembangkan dan meningkatkan mutu lembaga. Dalam penelitian ini, peneliti menggunakan penelitian kualitatif dan sumber datanya melalui wawancara bersama pimpinan pondok. Peluang pengembangan Pesantren di Luwu Utara, tergolong dalam sub sistem pendidikan Nasional di Indonesia yang bertujuan untuk mencerdaskan bangsa, menjadikan manusia yang beriman dan bertaqwa kepada Tuhan yang Maha Esa, berakhlak mulia, sehat, berilmu, cakap, kreatif, mandiri dan menjadi warga negara yang demokratis serta bertanggung jawab. Selain itu, pondok pesantren As'adiysh Belawa Baru, dianggap berhasil dikarenakan santri-santri terlibat langsung dalam masyarakat, misalnya di bulan Suci Ramadhan, santri ini dikirim untuk jadi Imam disetiap Masjid yang ada di Malangke. Namun di luar keberhasilan, ada beberapa beberapa hambatan yang dihadapi oleh pondok Pesantren As'adiysh Belawa Baru (Malangke) di antaranya: 1)Sistem kurikulum yang lebih modern, sehingga pesantren ketinggalan jauh dari sekolah umum, 2) Kurangnya anggaran dan sumber pendanaan disebabkan oleh kurang siswa. 3) adanya sebagian orang tua tidak tertarik menyekolahkan anak di sekolah Pesantren.

Kata Kunci : Model Kepemimpinan, Transformasional; Pendidikan Islam 
Al-Tanzim : Jurnal Manajemen Pendidikan Islam

E-ISSN: 2549-5720 P-ISSN: 2549-3663

March 2019, Vol. 03 No. 01, p. 82-101

https:// ejournal.unuja.ac.id/ index.php/al-tanzim

\section{PENDAHULUAN}

Mencermati fenomena yang ada sekarang, nampaknya sebagian besar anak-anak usia sekolah lebih cenderung memilih sekolah-sekolah "umum" dari pada pesantren . Pilihan seperti itu dilatarbelakangi oleh bergesernya nilai, motivasi dan orientasi dalam menuntut ilmu. Pada masa dahulu menuntut ilmu lebih didorong oleh keinginginan luhur dan niat suci semata-mata untuk memiliki ilmu pengetahuan. Akan tetapi pada masa sekarang ini orientasinya berkembang dan terkait erat dengan lapangan dan kesempatan kerja di masa mendatang.

Oleh karena itu sekali lagi kemampuan pemangku kepentingan dari lembaga pondok pesantren dalam merencanakan strategi yang tepat akan menentukan prospeknya di masa mendatang (Warliah, 2017). Peluang dan kekuatan yang dimiliki adalah modal utama untuk mengatasi tantangan global agar tetap eksis memberi warna jelas bagi pendidikan generasi mendatang yang penuh dengan dinamika perubahan yang begitu cepat dan kompleks.

Pesantren selanjutnya diharapkan tidak hanya mencetak ulama-ulama dibidang agama saja tetapi juga dituntut untuk memberi bekal kemampuan dibidang ilmu pengetahuan dan teknologi (Bali, 2017). Perubahan ini menjadi tantangan baru bagi pesantren untuk terus melakukan modernisasi dan inovasi agar pendidikan 
Al-Tanzim : Jurnal Manajemen Pendidikan Islam

E-ISSN: 2549-5720 P-ISSN: 2549-3663

March 2019, Vol. 03 No. 01, p. 82-101

https:// ejournal.unuja.ac.id/index.php/al-tanzim

pesantren mampu mengikuti perkembangan global (Ilmy, Wahid, \& Muali, 2018). Jika pesantren mampu menjawab tantangan itu, maka eksistensinya akan tetap aktual sebagai benteng pertahanan utama peradaban Islam kini dan masa yang akan datang.

Sehubungan dengan hal tersebut eksistensi pondok pesantren di wilayah Tana Luwu, khususnya pondok pesantren yang ada di Kabupaten Luwu Utara juga mengalami situasi dan kondisi yang kurang lebih sama dengan kondisi pondok pesantren yang ada di Nusantara pada umumnya. Ditengah upaya untuk tetap eksis dengan mengakses kemoderenan tetap saja ditemui kondisi lembaga pondok pesantren yang mengalami situasi kritis dan memprihatinkan.

Padahal dalam sejarah Islam Nusantara disebutkan bahwa wilayah Kerajaan Luwu pada masa lampau adalah Kerajaan pertama di Sulawesi Selatan yang menerima Islam sebagai agama resmi kerajaan. Berkembangnya Islam di Luwu adalah berkat perjuangan Datuk Sulaiman dan dua rekannya yang bernama Datuk Ribandang dan Datuk Tiro yang berasal dari Minangkabau (Sumatera). Pada mulanya ketiga Datuk menemui Tandi Pau (Maddika Bua saat itu) dan setelah terjadi dialog yang pada waktu itu dikenal dengan nama "Singkarume" (dialog menyambut tamu yang dilengkapi dengan adu kesaktian) maka Tandi Pau memeluk Islam pada senin tanggal 12 Rabiul Awal 1013 
Al-Tanzim : Jurnal Manajemen Pendidikan Islam

E-ISSN: 2549-5720 P-ISSN: 2549-3663

March 2019, Vol. 03 No. 01, p. 82-101

https:// ejournal.unuja.ac.id/ index.php/al-tanzim

H/1593 M. Selanjutnya diikuti oleh Pajung/Datu Luwu Pati Arase Daeng Parabung yang memeluk Islam pada tanggal 15 Ramadhan 1013H/1953 M. Selanjutnya Agama Islam pun berkembang dengan dengan cepat keseluruh wilayah Kerajaan Luwu yang pada saat itu pusat pemerintahannya berada di Malangke (Siodja Daeng Mallonjo, 2004).

Setelah berhasil mengislamkan Datu Luwu Islampun dijadikan Agama resmi kerajaan. Kemudian Datuk ri Bandang dan Datuk Tiro melanjutkan penyebaran Islam didaerah lain di Sulawesi Selatan. Sedangkan Datok Sulaiman tetap tinggal di Luwu agar bisa meng-Islamkan seluruh rakyat Luwu karena hal ini membutuhkan waktu yang cukup lama. Datuk Sulaiman menetap di Luwu hingga wafat dan dimakamkan di Malangke, tepatnya di Desa Pattimang dan ia pun diberi gelar Datok Pattimang (Anton Andi Pangerang, 2002).

Dalam kaitannya dengan pendidikan, jasa Datuk Pattimang dan para saudaranya yang telah meng-Islamkan Kerajaan Luwu, amat besar pengaruhnya bagi kelangsungan hidup beragama masyarakat Tana Luwu sejak dahulu sampai sekarang. Berdasarkan penelusuran sementara, penulis tidak menemukan keterangan tentang bentuk lembaga pendidikan resmi seperti seperti sekolah, madrasah ataupun Pondok Pesantren yang diwariskan para Datuk penyiar Islam di Luwu sebagaimana para penyiar Islam di Jawa dan Sumatera. 
Al-Tanzim : Jurnal Manajemen Pendidikan Islam

E-ISSN: 2549-5720 P-ISSN: 2549-3663

March 2019, Vol. 03 No. 01, p. 82-101

https:/ / ejournal.unuja.ac.id/ index.php/ al-tanzim

Namun demikian Datuk Sulaiman dan pengikutnya telah berhasil membangun Rumah Ibadah atau Mesjid dalam bentuk sederhana pada tanggal 1 Rajab 1013 H / 1593 M yang bertempat di Dusun Tina Rigella, di daerah Bua sekitar $10 \mathrm{~km}$ arah selatan pusat Kota Palopo. Mesjid pertama di Tanah Luwu ini sekaligus merupakan Mesjid pertama di Sulawesi. Selanjutnya pada tahun 1604 M didirikan pula Mesjid Tua Palopo oleh Raja Luwu yakni Datu Payung Luwu ke XVI Pati Pasaung Toampanangi Sultan Abdullah Matinroe (http://id.m.wikipedia. Org/wiki/Masjid Tua Palopo, 04 Maret 2017).

Hal ini mengisyaratkan sebuah tugas mulia bagi generasi selanjutnya untuk melanjutkan perjuangan beliau menyebarluaskan syiar Islam melalui lembaga pendidikan yang terorganisir dengan baik dan memiliki legalitas formal seperti madrasah dan pondok pesantren.

Diakui oleh para ahli sejarah bahwa lembaga pendidikan Islam pertama yang didirikan di Indonesia dan masih bertahan sampai sekarang adalah dalam bentuk pondok pesantren. Dengan karakternya yang khas dengan orientasi religus, pesantren telah mampu meletakkan dasardasar pendidikan keagamaan yang kuat. Para santri tidak hanya dibekali pemahaman tentang ajaran Islam tetapi juga kemampuan untuk menyebarkan dan mempertahankan Islam. 
Al-Tanzim : Jurnal Manajemen Pendidikan Islam

E-ISSN: 2549-5720 P-ISSN: 2549-3663

March 2019, Vol. 03 No. 01, p. 82-101

https:// ejournal.unuja.ac.id/ index.php/al-tanzim

Pada awal berdirinya, pesantren merupakan lembaga pendidikan yang sangat sederhana. Tidak ada klasifikasi kelas, tidak ada kurikulum, juga tidak ada aturan yang baku di dalamnya. Dalam praktik pembelajarannya, semuanya bergantung pada kyai sebagai poros sistem pembelajaran pesantren (Fauzi, 2018). Mulai dari jadwal, metode, bahkan kitab yang hendak diajarkan, semua merupakan wewenang seorang kyai secara penuh (Amin Haedari, 2004).

Hal tersebut memberikan gambaran bahwa dalam tubuh pondok pesantren sejak dahulu telah ada upaya untuk mengikuti perkembangan zaman dengan membuka pendidikan formal yang merupakan cikal bakal serta ciri pendidikan modern (Hefniy, 2016). Membuka diri untuk menerima modernisasi bagi lembaga pendidikan Islam seperti pondok pesantren adalah satu hal yang tidak dapat dihindari.

Seiring dengan perkembangan zaman pondok pesantren dituntut untuk mengikuti dinamika perubahan tidak hanya mencetak ulama-ulama dibidang agama yang akan berperan aktif dalam penyebaran agama Islam. Perubahan ini menjadi tantangan baru bagi pesantren untuk inovasi agar pendidikan pesantren mampu mengikuti perkembangan global. Jika pesantren mampu menjawab tantangan itu, maka eksistensinya akan tetap aktual sebagai benteng pertahanan utama peradaban Islam kini dan 
Al-Tanzim : Jurnal Manajemen Pendidikan Islam

E-ISSN: 2549-5720 P-ISSN: 2549-3663

March 2019, Vol. 03 No. 01, p. 82-101

https:// ejournal.unuja.ac.id/index.php/al-tanzim

sekaligus menentukan prospek perkembangannya pesantren.

Proses perubahan yang terjadi di berbagai pondok pesantren pasca abad ke-19 pada dasarnya merupakan upaya pesantren secara perlahan-lahan dalam rangka membuka diri bagi masuknya modernisasi. Modernisasi dalam tubuh pesantren berarti sebuah proses menuju perubahan (M. Dalyono, 2007). Tantangan zaman modern pada hakekatnya adalah tantangan IPTEK. Pada masa awalnya implikasi dari kemodernan itu jelas positif, yaitu berupa kemajuan-kemajuan yang dihasilkan oleh ilmu pengetahuan dan teknologi. Dalam dunia pesantren, wawasan santri terhadap dunia luar kian terbuka. Pesantren bukan lagi komunitas eksklusif seperti dirasakan pada zaman-zaman pra kemerdekaan, namun setelah masa kemerdekaan hingga dewasa ini telah banyak lulusan output dari pesantren yang telah memiliki pembaharuan pemikiran baik di dalam pesantren maupun di luar pesantren.

Di tengah harapan dan tuntutan yang begitu tinggi bagi pondok pesantren, untuk menyambut modernisasi kelembagaannya yang tidak kunjung berakhir, dihadapkan pula implikasi negatif kemoderenan berupa merosotnya nilai-nilai kehidupan rohani, tercabutnya budaya-budaya lokal, dan degradasi moral (terutama) yang melanda generasi muda. Dampak sistemik lainnya adalah terjadi kemerosotan terhadap kualitas output produk sistem 
Al-Tanzim : Jurnal Manajemen Pendidikan Islam

E-ISSN: 2549-5720 P-ISSN: 2549-3663

March 2019, Vol. 03 No. 01, p. 82-101

https:// ejournal.unuja.ac.id/ index.php/al-tanzim

pesantren, termasuk terjadinya kelangkaan out put yang dapat disebut ulama dengan predikat sebagai "Pewaris Nabi" (warastsatul Anbiya). Oleh karenanya Gus Zaenal dalam bukunya "Runtuhnya Singgasana Kyai" tengah berupaya mengembalikan dunia pesantren kepada fitrahnya, yakni sebagai lembaga pendidikan yang lebih mengedepankan kualitas moral (Chabib Thoha dan Muth'i, 2003).

Di sisi lainnya, berbagai penelitian sudah membuktikan bahwa pesantren tidak hanya sebagai lembaga yang kaku dan melulu mengkaji kitab-kitab klasik. Pesantren saat ini turut serta membangun kehidupan masyarakat sekitar, baik dalam keagamaan, ekonomi, sosial, pendidikan maupun politik.

Melihat eksistensi dan berbagai fungsi, peran serta tuntutan yang harus dijalankan oleh pondok pesantren yang semakin beragam, ditambah segudang masalah yang ada didalamnya, maka dalam penelitian ini ingin dikaji lebih jauh mengenai eksistensi, pola strategi pengembangan dengan peluang yang dimiliki serta tantangan yang dihadapi pondok pesantren.

\section{METODE PENELITIAN}

Jenis penelitian yang akan digunakan adalah kualitatif. Penelitian kualitatif merupakan penelitian yang deskriptif yang mengikapi dalam permasalahan (Hadari Nawawi, 
Al-Tanzim : Jurnal Manajemen Pendidikan Islam

E-ISSN: 2549-5720 P-ISSN: 2549-3663

March 2019, Vol. 03 No. 01, p. 82-101

https:// ejournal.unuja.ac.id/index.php/al-tanzim

1996). Penelitian kualitatif (qualitative research) merupakan suatu payung konsep yang meliputi berberapa format penelitian yang akan membantu memahami dan menjelaskan makna fenomena sosial dari setting alamiah yang ada (Sharan B. Mariam, 1998).

Peneliti melakukan wawancara, observasi, dokumentasi guna mendapatkan informasi, pendapat, tanggapan, pemikiran, persepsinya, serta pemahaman diperoleh melalui analisis berbagai ketertarikan dari partisipan, dan melalui penguraian tentang situasi-situasi dan peristiwa (Nurtain, 1991).

\section{HASIL PENELITIAN}

Pesantren As'adiyah Belawa Baru diawali dengan pendirian yayasan oleh H. Latang tahun 1986, dan pada tahun 2000 lahir Pondok Pesantren As'adiyah Belawa Baru sebagai pusat pendidikan dan pengembangan budaya toleran serta budaya perdamaian.

Pesantren As'adiyah Belawa Baru berlokasi di desa Pattimang Kecamatan Malangke Kabupaten Luwu Utara, dengan luas 2 Hektar. Lokasi pondok sangat strategis ditinjau dari segi kemudahan mendapatkan sarana transportasi. Jarak Ponpes dari Kabupaten Luwu Utara sekitar $35 \mathrm{Km}$, ke arah selatan Kota Masamba.

Untuk membina santri/santriwati yang terdiri 4 tingkatan yakni: TK, MI, MTs dan MA. Sistem pendidikan 
Al-Tanzim : Jurnal Manajemen Pendidikan Islam

E-ISSN: 2549-5720 P-ISSN: 2549-3663

March 2019, Vol. 03 No. 01, p. 82-101

https:// ejournal.unuja.ac.id/ index.php/al-tanzim

formal menjadi dasar pendidikan dengan kurikulum Kementerian Agama dan Diknas menjadi pilihan. Dari kedua lembaga pendidikan terebut Pesantren telah mendapatkan akreditasi dengan status diakui lewat SK Dirjen Bimbingan Islam. Selain kurikulum Kementerian Agama dan Diknas, pesantren juga memasukkan kurikulum kepesantrenan. Para santri mendapat pendidikan al-Qur'an, pendalaman kitab-kitab kuning dan bahasa Arab dan Inggris. Adapun pemberian materi disesuaikan dengan jadwal sekolah yang ada. Selain itu, santri juga mendapat berbagai kegiatan ekstrakurikuler seperti kegiatan olahraga, pramuka, palang merah, belajar komputer dan kegiatan lainnya.

Sehingga kini, jumlah santri yang belajar di Pesantren Belawa Baru sebanyak 626 santri. Dari keseluruhan santri 35 \% santri tinggal di Asrama, sementara $65 \%$ merupakan santri yang berasal dari masyarakat sekitar.

Pondok Pesantren As'adiyah Belawa Baru berada di jalan poros Kecamatan Malangke dan Masamba, suatu daerah yang cukup terkenal di Kabupaten Luwu Utara. Pondok Pesantren As'adiyah Belawa Baru di Kecamatan Malangke dikenal karena beberapa faktor. Pertama, daerah Malangke ini sejak masa silam dikenal dengan khazanah keagamaan yang menonjol di Luwu karena adanya tokoh agama (Datok Sulaiman) mengajarkan serta mengasuh warga masyarakat Malangke. Kedua, memiliki 
Al-Tanzim : Jurnal Manajemen Pendidikan Islam

E-ISSN: 2549-5720 P-ISSN: 2549-3663

March 2019, Vol. 03 No. 01, p. 82-101

https:/ / ejournal.unuja.ac.id/ index.php/ al-tanzim

masjid/mushollah dan bahasa bugis, yang memudahkan penyebar agama Islam dan kini memiliki bangunan Masjid/mushollah yang menyerupai masjid/mushollah Nabawi. Melihat perkembangan dunia pendidikan dewasa ini semakin kompetitif. maka pengelolah pesantren melakukan perombakan beberapa aspek diantaranya:

1. Pola Manajemen Kurikulum Pondok Pesantren As'adiyah Belawa Baru

Di Pondok Pesantren As'adiyah Belawa Baru berlaku 3 jenis kurikulum, yaitu: Kurikulum Kementerian Agama, terdiri dari Kurikulum 2013 untuk mata pelajaran Agama dan Bahasa Arab dan Kurikulum Tingkat Satuan Pendidikan (KTSP) untuk mata pelajaran umum sesuai dengan jenjang pendidikan, serta Kurikulum Takhassus (khusus) sebagai kurikulum khas Pondok Pesantren As'adiyah Belawa Baru. Di sini terlihat bahwa pengembangan kurikulum di Ponpes As'adiyah Belawa Baru memadukan antara kurikulum yang bersifat umum (berisi mata pelajaran formal) dengan Kurikulum Takhassus (berisi pembelajaran Kitab Kuning) sehingga menghasilkan suatu bentuk KTSP Pondok Pesantren As'adiyah Belawa Baru dengan proporsi lebih banyak justru diberikan kepada Kurikulum Takhassus. Hal ini menjadikan kurikulum Ponpes As'adiyah Belawa Baru tergolong cukup unik. 
Al-Tanzim : Jurnal Manajemen Pendidikan Islam

E-ISSN: 2549-5720 P-ISSN: 2549-3663

March 2019, Vol. 03 No. 01, p. 82-101

https:// ejournal.unija.ac.id/ index.php/al-tanzim

Seperti apa yang telah dijabarkan oleh Syamsuddin Jafar bahwa secara praktis konsep kurikulum yang diterapkan di sekolah-sekolah yaitu KTSP. KTSP atau kurikulum 2006 berisi seperangkat rencana dan pengaturan tentang program pendidikan yang dibakukan untuk mencapai tujuan nasional dan cara pencapaiannya disesuaikan dengan keadaan dan kemampuan daerah dan satuan pendidikan (pondok pesantren) (Syamsuddin Jafar, 2017).

2. Pola manajemen pendidik dan tenaga kependidikan (PTK) Pondok Pesantren As'adiyah Belawa Baru

Manajemen sumber daya manusia atau dalam lembaga pendidikan, merupakan manajemen yang memfokuskan kajiannya pada pengelolaan sumber daya manusia yang ada. Pengembangan sumber daya manusia yang ada dalam lembaga pendidikan, dibagi ke dalam beberapa area kerja meliputi; desain organisasi, pengembangan organisasi, perencanaan dan pengembangan karir pegawai, perencanaan sumber daya manusia yang ada, sistem kinerja pegawai, kompensasi dan gaji yang didapat, serta kearsipan pegawai.

Hal yang perlu dipahami bahwa pilar utama dalam membangun suatu organisasi yang berwawasan global adalah kompetensi individu yang ada dan 
Al-Tanzim : Jurnal Manajemen Pendidikan Islam

E-ISSN: 2549-5720 P-ISSN: 2549-3663

March 2019, Vol. 03 No. 01, p. 82-101

https:/ / ejournal.unuja.ac.id/ index.php/ al-tanzim

tergabung dalam organisasi. Di samping itu, pola pembinaan berkesinambungan melalui kegiatan pendidikan dan pelatihan, workshop peningkatan mutu, di samping itu lembaga juga perlu mempersiapkan adanya masa orientasi agar pegawai mampu bekerja dan mengembangkan karirnya sesuai dengan yang diharapkan.

Masa orientasi ini perlu didesain sebaik mungkin karena merupakan masa transisi. Kegiatan pada masa orientasi terbatas pada waktu tertentu, dan dapat berupa pelatihan atau kegiatan apa saja yang wajib diikuti oleh setiap individu untuk memenuhi standar yang diharapkan. Selanjutnya masa orientasi ini dapat diteruskan dengan "masa pemantapan" dengan pola yang sama dengan orientasi hanya kadar kompetensi yang dituntut berbeda.

3. Pola Manajemen Sarana dan Prasarana Pondok Pesantren As'adiyah Belawa Baru

Pada hakikatnya manajemen sarana dan prasarana pendidikan di sekolah atau madrasah merupakan proses pendayagunaan semua sarana dan prasarana yang dimiliki sekolah. Manajemen sarana dan prasarana pendidikan merupakan seluruh rangkaian proses kegiatan yang direncanakan dan diusahakan secara sengaja dan bersungguh-sungguh serta 
Al-Tanzim : Jurnal Manajemen Pendidikan Islam

E-ISSN: 2549-5720 P-ISSN: 2549-3663

March 2019, Vol. 03 No. 01, p. 82-101

https:// ejournal.unuja.ac.id/ index.php/al-tanzim

pembinaan secara kontinu terhadap benda-benda pendidikan, agar senantiasa selalu dalam keadaan siap pakai (ready to use) untuk proses pembelajaran sehingga proses belajar mengajar semakin efektif dan efisien bagi peningkatan mutu pembelajaran dan tercapainya tujuan pendidikan yang telah ditetapkan.

Hal penting yang terlihat dalam pengadaan sarana dan prasarana di Pondok Pesantren As'adiyah Belawa Baru adalah adanya penyesuaian dengan dana yang dimiliki oleh madrasah. Jika sarana dan prasarana dalam pengadaannya membutuhkan dana yang tidak begitu besar dan dana madrasah masih bisa mencukupinya maka akan segera direalisasikan (Alimuddin, 2017). Tetapi jika sarana dan prasarana membutuhkan dana yang besar maka pengadaan tersebut ditunda dahulu sampai dana yang dibutuhkan sudah dimiliki madrasah.

Setelah sarana dan prasarana yang diperlukan telah dimiliki oleh madrasah dan diserahkan kepada bagian sarana dan prasarana maka langkah selanjutnya adalah melakukan inventarisasi. Proses inventarisasi sarana dan prasarana ini umumnya dilaksanakan dengan cara melakukan pencatatan ke dalam buku inventaris dan menuliskan kode atau nomor tertentu pada fisik barang. Kegiatan inventarisasi sarana dan prasarana ini sangat dibutuhkan untuk mengetahui 
Al-Tanzim : Jurnal Manajemen Pendidikan Islam

E-ISSN: 2549-5720 P-ISSN: 2549-3663

March 2019, Vol. 03 No. 01, p. 82-101

https:/ / ejournal.unuja.ac.id/ index.php/ al-tanzim

sarana prasarana apa saja yang belum dimiliki dan dibutuhkan oleh warga sekolah sehingga permintaan barang dapat dilakukan dengan maksimal dan cepat diadakan. Inventarisasi sarana dan prasarana yang baik dan teratur akan berimbas pada kateraturan pemakaian dan pemanfaatan sarana prasarana oleh semua warga sekolah.

4. Pola Manajemen Hubungan Masyarakat Pondok Pesantren As'adiyah Belawa Baru

Berkaitan dengan pola manajemen hubungan masyarakat (humas) di Pondok Pesantren As'adiyah Belawa Baru cenderung ke arah "pola tradisional" di mana komunikasi madrasah dengan manajemen lainnya seperti manajemen PTK ataupun juga manajemen pembiayaan orang tua atau masyarakat masih didominasi oleh keberadaan komite madrasah. Komite madrasah dalam hal ini masih sebatas peran normatif, utamanya dalam mengikuti kegiatan-kegiatan yang dilaksanakan oleh pondok atau madrasah, seperti pengembangan pesantren, madrasah, pengajian, dan kegiatan haul di pesantren. Di samping itu, peran wali santri juga belum terlihat maksimal terutama dalam memberikan masukan dan mengawasi perkembangan madrasah/pondok secara aktif. 
Al-Tanzim : Jurnal Manajemen Pendidikan Islam

E-ISSN: 2549-5720 P-ISSN: 2549-3663

March 2019, Vol. 03 No. 01, p. 82-101

https:// ejournal.unuja.ac.id/ index.php/al-tanzim

Pondok dengan masyarakat sehingga program kegiatan madrasah/pondok lebih berorientasi pada kebutuhan masyarakat. Hal ini sesuai dengan pendapat Harisma yang menjelaskan bahwa secara nyata hubungan antara sekolah dengan masyarakat bertujuan untuk: a) meningkatkan kualitas pembelajaran dan pertumbuhan peserta didik, b) memahami kebutuhankebutuhan masyarakat yang sekaligus menjadi desakan, c) mengembangkan program-program sekolah ke arah lebih maju dan lebih membumi Peluang dan tantangan Pondok Pesantren di Kecamatan Malangke.

\section{KESIMPULAN}

Eksistensi pondok pesantren di Luwu Utara memiliki dua sistem kurikulum yaitu kurikulum Diknas dan Kementerian Agama, hal ini dilakukan supaya tidak kalah saing dengan sekolah umumnya. Namun demikian, Pondok pesantren mulai bertahap untuk maju salah satu adalah Pondok Pesantren As'adiysh Belawa Baru (Malangke) yang memiliki siswa banyak sekitar 626 siswa, hal ini menunjukkan bahwa eksistensi pesantren di Malangke.

Strategi yang dilakukan adalah: (1) kebijaksanaan dan kewenangan sekolah berpengaruh langsung dengan siswa, orang tua dan guru (2) selalu bertujuan untuk mengoptimalkan sumber daya sekolah (3) efektif dalam melakukan pembinaan peserta didik seperti kehadiran, hasil 
Al-Tanzim : Jurnal Manajemen Pendidikan Islam

E-ISSN: 2549-5720 P-ISSN: 2549-3663

March 2019, Vol. 03 No. 01, p. 82-101

https:/ / ejournal.unuja.ac.id/ index.php/ al-tanzim

belajar, tingkat pengulangan, tingkat putus sekolah, moral guru dan iklim sekolah (4) adanya perhatian bersama untuk mengambil keputusan, memberdayakan guru, manajemen sekolah, pengembangan sekolah, dan perubahan perencanaan.

\section{DAFTAR PUSTAKA}

Andi Pangerang, Anton. (2002). Andi Djemma-Datu Luwu, (Jakarta Selatan: Yayasan Bina Profesi dan Wirausaha (BENUA), www/http.Sejarahislamdimalangke.com. diakses, Pada tanggal 25 Februari 2017.

Arikunto, Suharsimi. (2006). Penelitian Tindakan Kelas, Jakarta: Bumi Aksara.

Bali, M. M. E. I. (2017). Perguruan Tinggi Islam Berbasis Pondok Pesantren. Al-Tanzim, 1(2), 1-14.

B. Mariam, Sharan (1998). Qualitative Research and Case Study Application in Education, San Fransisco: Jossey-Bass Publishers.

Creswell, John, W. (1998). Research Design: Pendekatan

Kualitatif, Kuantitatif, dan Mixed, Yogjakarta: Pustaka Pelajar 
Al-Tanzim : Jurnal Manajemen Pendidikan Islam

E-ISSN: 2549-5720 P-ISSN: 2549-3663

March 2019, Vol. 03 No. 01, p. 82-101

bttps:/ / ejournal.unuja.ac.id/ index.php/ al-tan₹im

Daeng Mallonjo, H. Siodja, (2007). "Kerajaan Luwu: Catatan Tentang Sawerigading, Sistem Pemerintahan dan Masuknya Islam" Palopo: Komunitas Kampung Sawerigading (Kampus) bekerja sama dengan Pemerintah Kota Palopo, 2004.

Dalyono, M., Psikologi Pendidikan, Jakarta: Rineka Cipta.

Fauzi, A., Baharun, H., Mundiri, A., \& Manshur, U. (2018).

E-Learning in Pesantren: Learning Transformation based on the Value of Pesantren E-Learning in Pesantren: Learning Transformation based on the Value of Pesantren. Journal of Physics: Conference Series, (1114 012062), 1-6.

H. McMillan, James \& Sally Schumacher. (2000). Research In Education: A Conceptual Introduction, Publisher: Allyn \& Bacon.

Haedari, Amin, dkk. (2004). Panorama Pesantren dalam Cakrawala Modern, Jakarta: Diva Pustaka.

Hefniy. (2016). Kyai Leadership in Improving

Organizational PErformance in Pesantren. Proceeding, 2nd ICET Theme:"Improving The Quality Of Education And Training Through Strengthening Networking," 324.

Johnson, Burke \& Lary Cristenson. (2004). Educatonal Research: Quantitative, Qualitative, and Mixed Approaches, Boston: Pearson Educationa.

Joseph A. Maxwell. (2012). Qualitative Research Design: An Interactive Approach, Sage. 
Al-Tanzim : Jurnal Manajemen Pendidikan Islam

E-ISSN: 2549-5720 P-ISSN: 2549-3663

March 2019, Vol. 03 No. 01, p. 82-101

https:// ejournal.unuja.ac.id/index.php/al-tanzim

K. Yin, Robert. (2010). Qualitative Research from Start to Finish, Guilford Press.

Lawrence Berg, Bruce \&Howard Lune. (2004). Qualitative Research Methods for the Social Sciences, Vol. 5. Boston: Pearson.

Masjid Tua Palopo," Wikipedia bahasa Indonesia, ensiklopedia bebas. http://id.m.wikipedia._Org/wiki/Masjid Tua Palopo, 04 Maret 2017.

Moleong, Lexy J., Metodologi Penelitian Kualitatif, Remaja Rosdakarya, Bandung: 2005.

Nawawi, Hadari. (1996). Penelitian Terapan, Yogyakarta:

Gajah Mada, University Press,

Nurtain. (1991). Analisis Item, Yogyakarta: UGM

Ruiz Olabuénaga, José Ignacio. (2012). Metodología de La Investigación Cualitativa, Vol. 15. Universidad de Deusto.

Sugiyono, (2008). Metode Penelitian Kuantitatif, Kualitatif, dan $R \in D$, Bandung: Alfabeta.

Thoha, Chabib dan Muth'i, A. (2003). PBM-PAI di Sekolah:

Eksistensi dan Proses Belajar Mengajar Pendidikan Agama Islam, Yogyakarta: Pustaka Pelajar bekerja sama dengan Fak. Tarbiyah 1AIN Walisongo Sernarang.

Warliah, W. (2017). Pendidikan Berbasis Gender Awareness :

Strategi Meminimalisir Bias Gender di Pondok Pesantren. Jurnal Islam Nusantara, 1(2), 118-130. 